\title{
DETERMINATION OF DIVIDEND POLICY OF MANUFACTURING COMPANIES IN INDONESIA
}

\author{
Husaini $^{1}$, Marzuki ${ }^{2}$, Nurhasanah ${ }^{3}$ \\ 1,2,3 Faculty of Economics and Business, Malikussaleh University, Lhokseumawe \\ E-mail: ${ }^{1)}$ husaini@unimal.ac.id, ${ }^{2)}$ marzuki@unimal.ac.id, ${ }^{3)}$ nurhasanah@unimal.ac.id
}

\begin{abstract}
This study examines the factors that determine (determination) dividend policy in manufacturing companies in Indonesia. In general, economic conditions in Indonesia are still in the emerging market category. As a developing country, Indonesia's capital market is relatively large and has its own characteristics which are reflected in investor behavior and government regulations in the capital market. Indonesia, in its behavior in the capital market adheres to a civil law system, meaning that investors are given the widest freedom to conduct transactions in the capital market, especially in the wrong amount owned by investors. The variables used to analyze dividend policy are profitability, free cash flows, firm size and leverage. This study only focuses on manufacturing companies that distribute dividends with an observation period from 2015-2019. The sampling method used purposive sampling and obtained 145 companies that distribute dividends. The data was processed using panel data regression analysis with analysis tools using E-Views software. From the research, it is found that the ROA and F_SIZE variables have a positive and significant effect on the DPR. FCF and Leverage variables measured by (TDTE) have a negative and significant effect on dividend policy as measured by the DPR in manufacturing companies in Indonesia.
\end{abstract}

Keywords: DPR, ROA, FCF, Firms size and Leverage.

\section{INTRODUCTION}

Dividend policy is related to the use of earnings (earnings) obtained by the company, whether the profits are divided as dividends or reinvested in the form of retained earnings (retained earnings). Some research results on dividends are still debatable. So that until now dividends is still a topic of discussion. This condition is caused by the different attitudes of managers and investors in dividend policy. Company policies related to dividend payments interact with potential conflicts between company owners and non-owner stakeholders. The potential for conflict also occurs when there is a separation between ownership and management (Jensen and Meckling, 1976).

In addition, dividends can be used as an indicator in assessing the performance of a company. If the company is able to pay dividends every year, it indicates that the company's performance is good. Determining the right dividend policy is an important task for managers because it has an impact on capital budgeting, capital structure and the company's stock price in the market. On the other hand, dividend policy has an impact on shareholder wealth and all economic activities (Jabbouri, 2016), and also has an impact on investment policy, corporate funding and corporate finance.

The information contained in the dividend decision will be responded to by investors. Investors will analyze and make decisions, whether to buy, sell or maintain these shares (Tandelilin, 2010). Considering that dividend policy has an influence on investors' decisions, the management will pay serious and proper attention to determining dividend policy.

Previous research that has been done related to dividend payment policies, among others, Jabbouri (2016) found that dividend policy is positively related to firm size, profitability, and liquidity and negatively related to leverage, growth, free cash flow and economic conditions. The

International Journal of Economic, Business, Accounting, Agriculture Management and Sharia Administration |IJEBAS

E-ISSN: 2808-4713 | https://radjapublika.com/index.php/IJEBAS 
negative relationship with free cash flow is an indication of the possibility of conflict between managers and investors or better known as agency conflict (Jensen \& Meckling, 1976). Conflict agency also often occurs when managers determine dividend policy.

In research related to the determination of dividend policy, the variables used include profitability, free cash flows, firm size and leverage (debt). For the profitability factor, the variable used is Return on Assets (ROA). Return on Assets is a ratio that shows how much the company's assets are able to generate profits. Return on Assets is a ratio that is able to show the company's financial performance (Kasmir, 2010). Free Cash Flow is the remaining cash flow after the company pays its operational expenses and investment needs and this is the cash flow that determines the value of a company/share (Munawir, 2012).

Meanwhile, firm size is the amount of total assets owned by the company. The greater assets would give the opportunity of companies to pay dividend to investors. The results showed that there was a positive relationship between dividends and firm size. Holder et al. (1998) revealed that large firms have better access to capital markets and find it easier to raise funds at lower costs, which allow them to pay higher dividends to shareholders. This shows a positive relationship between dividend payments and firm size, Jensen et al., 1992; Redding, 2010 and Al-Malkawi, 2011).

Leverage (debt) is also a variable observed in this study. The development of the Company's leverage (debt) fluctuates from time to time. The average leverage ratio then experienced a slight increase of $128.5 \%$ for the 2014-2016 periods (Setyawan, 2017). High leverage indicates that the company tends to use external funds in financing the company. This will cause the company to be able to benefit from avoiding tax payments. The description shows that the high capital structure will have a positive effect on the dividend rate.

In Indonesia, the behavior of investors in the capital market adheres to a civil law system, meaning that investors are given the widest freedom to conduct transactions in the capital market, especially in the wrong amount owned by the investor. This condition makes researchers interested in studying further related to the determination of dividend policy, especially companies listed on the Indonesia Stock Exchange.

Based on the description that has been presented above, this research was conducted with the aim of analyzing whether profitability, free cash flow, firm size and debt will affect dividend policy in manufacturing companies on the Indonesia Stock Exchange..

\section{LITERATURE REVIEW}

\section{Agency Theory}

Agency theory (agency theory) explains that the owner of the company gives the mandate of the management of the company to the management. The view of agency theory where there is a separation between the agent and the principal which results in the emergence of potential conflicts. The management who has certain interests will tend to prepare profit reports that are in accordance with their objectives and not for the interests of the principal. Mature companies are able to generate income that can cover investment financing needs. Their free cash flow is divided in the form of dividends (Jensen, 1986). When company management maintains excessive free cash flow, there is potential for it to be used for personal gain. This will lead to poor corporate governance and agency conflicts to occur. Jensen (1986) mentions in theory referring to management's intention to invest in negative NPV projects, but dividend payments can eliminate this problem by controlling the cash available to managers (Litzenberger (1982)

\section{Profitability}

Profitability is the company's ability to generate profits. Kasmir (2014) said the profitability ratio is a ratio used to assess the company's profits in seeking a profit. One of the financial ratios 
used to see the performance of a company is the return on assets (ROA). Return on assets (ROA) is a comparison between profit before tax with the average total assets in a period (Kasmir, 2014). Meanwhile, ROA is a tool to analyze or measure the level of business efficiency and profitability achieved by the company concerned (Munawir, 2012). ROA is a tool to measure the company's management ability in managing its assets in order to obtain overall profits (Brigham and Hauston, 2013).

\section{Free Cash Flow}

FCF describes free cash, namely cash that can be distributed to investors after making some necessary reinvestment. Management can use FCF to determine the amount of cash that will be used for company expansion, debt repayment, dividend announcements, share repurchases, and other purposes. (Brigham and Hauston, 2013). Free cash flow can be one of the causes of agency conflict when managers do not use the cash properly. One example is when managers use free cash flow to invest in projects that generate zero or negative NPV. This is called the free cash flow agency problem. Free cash flow agency problem.

La Porta et al. (2000) add that when a firm has free cash flow, managers will engage in wasteful practices, even when protection for investors increases. A number of studies have shown that firms with greater "free cash flow" need to pay more dividends to reduce the agency costs of free cash flow (Jensen, 1986; Holder et al., 1998; La Porta et al., 2000; and Mollah et al. ., 2002). Based on the findings of the above study, it can be speculated that there is a positive relationship between free cash flow and dividend payout ratio.

\section{Firms Size}

Some previous researchers such as Jensen et al,(1992) and Redding (2010) show that large companies distribute a higher amount of net income as cash dividends, than small companies. Several studies have examined the impact of firm size on the dividend relationship. Large companies are more likely to increase dividend payments to reduce agency costs.

Support their findings Jensen and Meckling (1976), stating that agency costs are related to firm size. They are of the view that for large firms, widely dispersed ownership has greater bargaining control and in turn increases agency costs. Furthermore, Sawicki (2015) illustrates that dividend payments can indirectly help monitor the performance of managers in large companies. Paying large dividends can be a solution to such a problem because large dividends lead to an increased need for external financing, and the need for external funding leads to increased monitoring of large companies, due to the presence of creditors.

\section{Leverage (Debt)}

Leverage is used to measure the company's ability to pay all of its obligations, both long-term and short-term if the company is liquidated (Jogiyanto, 2010). Leverage can be measured from the ratio of the ratio of total debt to equity which is usually measured through the debt to equity ratio (DER). In the calculation, DER is calculated by dividing debt by total equity, meaning that if the company's debt is higher than its equity, the DER ratio is above one, so that the funds used for the company's operational activities are more of the debt element than its own capital (equity) (Kasmir, 2014).

Previous researchers found that risk is a significant factor in determining the dividend payout ratio. Gill, Biger, \& Tibrewala (2010) show a positive relationship between debt-to-equity ratio and dividend payout ratio in terms of the service sector. However, in the manufacturing sector of US firms, the relationship between the debt-to-equity ratio and the dividend payout ratio is negative. 


\section{IMPLEMENTATION METHOD}

The populations are manufacturing companies listed on the Indonesia Stock Exchange (www.idx.co.id). The sample was taken using the purposive sampling method, namely companies that paid dividends in a row from 2015 to 2019 . The number of samples that meet the requirements is 145 companies so that the number of observations is 725 data.

\section{Variable Operational Definition \\ Dividend Policy}

In this research, dividend policy is the dependent variable. Dividend policy in this study is proxy by the Dividend Payout Ratio which is expressed in percentage units. Dividend Payout Ratio can be calculated by the formula (Sartono, 2010):

$$
\text { Dividend }=\frac{\text { Dividen Per Share }}{\text { Earning Per Share }} \times 100 \%
$$

\section{Profitability}

Profitability in this study is an independent variable. Profitability is measured using Return on Assets (ROA) which is a profitability ratio that compares the company's profit with the company's total assets which is formulated as follows (Cahyo, 2017; Atmawati, 2010; Anam et al., 2017):

$$
R O A_{i t}=\frac{E A T_{i t}}{{\text { Total } \text { Aset }_{i t}}}
$$

\section{Free Cash Flow}

Free Cash Flow is the remaining cash flow after the company pays its operational expenses and investment needs and this is the cash flow that determines the value of a company/share. The formula for finding free cash flow is as follows (Atmawati, 2010; Basuki, 2017; Putri and Chabachip, 2013).

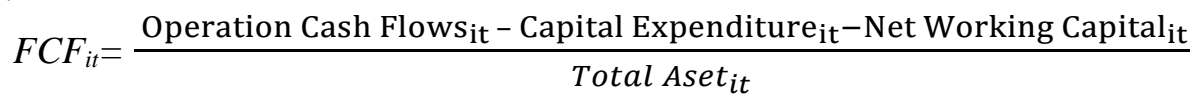

\section{Firms size}

Firm size is the size a company can use as a benchmark for assets. Because the company's total assets are of large value, this can be simplified by transforming into natural logarithms (Ghozali, 2006).

Company Size $=$ Ln Total Assets

\section{Leverage (debt)}

Leverage is a comparison between the amounts of debt used to finance investment compared to equity. Leverage is proxied by Total Debt to Equity (TDTE) or more popularly called DER (Saputro and Hindasah, 2017; Ayu, 2013; Cahyo, 2017) with the formula:

$$
\text { TDTE }=\frac{\text { Total Debt }_{\text {it }}}{\text { Total Equity }_{\text {it }}}
$$

\section{Data analysis method}

The method used to solve the problem in this research is multiple regression analysis of panel data with the help of the E-views program. Panel data analysis can be done with static panel data 


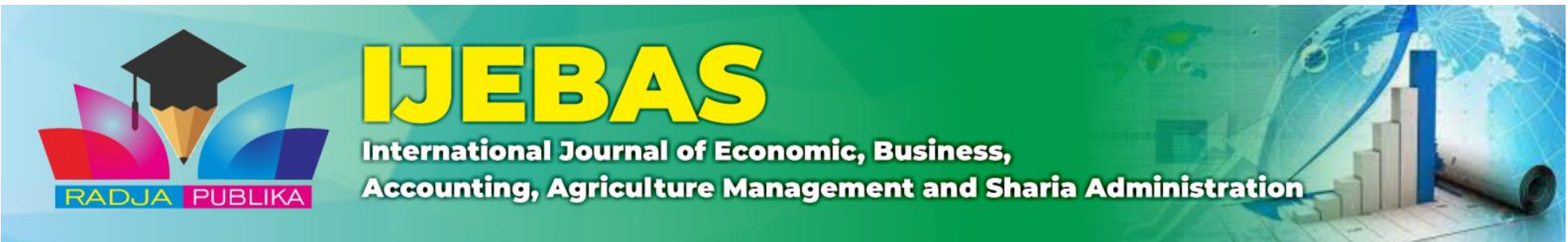

consisting of Ordinary Least Square (OLS), Fixed Effect Model (FEM) and Random Effect Model (REM). To get a good model, the Chow test and Housman test are carried out first.

The general estimation model in this study is as follows:

$$
Y_{i t}=\alpha+\beta_{1} X_{1 i t}+\beta_{2} X_{2 i t}+\beta_{3} X_{3 i t}+\beta_{4} X_{4 i t}+e_{i t}
$$

Description:

$\mathrm{Y}_{\text {it }} \quad$ : Dividend Payout Ratio period $\mathrm{t}$

i : $1,2,3 \ldots . . . \mathrm{N}$ (cross section)

$\mathrm{t}: 1,2,3 \ldots \mathrm{T}$ (time series)

$\alpha$ : Constant

$\beta_{1-5} \quad$ : Regression coefficient

$\mathrm{X}_{\text {it }} \quad$ : ROA at company i period $\mathrm{t}$

$\mathrm{X}_{2 \mathrm{it}} \quad$ : FCF at company i period $\mathrm{t}$

$\mathrm{X}_{3 \mathrm{it}} \quad$ : Firms Size at company i period $\mathrm{t}$

$\mathrm{X}_{4 \mathrm{it}} \quad$ : Total Debt to Total Equity (TDTE) at company i period $\mathrm{t}$

$\mathrm{e}_{\mathrm{it}} \quad$ : Error Term at company i period $\mathrm{t}$

Based on the above equation, the empirical model can be written for this research as follows:

Dividend $_{i t}=\alpha+\beta_{1}$ ROA $_{i t}+\beta_{2} F C F_{i t}+\beta_{3}$ Firms Size $_{i t}+\beta_{4} T D T E_{i t}+\mathrm{e}_{i t}$

\section{RESULTS AND DISCUSSION}

\section{Statistical Descriptive Analysis}

In descriptive statistical analysis, it will be seen the average value, maximum value, minimum value and standard deviation of the data used in this study. The results of the descriptive analysis in this study can be seen in the table below:

Table 1. Statistical Descriptive Analysis

\begin{tabular}{cccccc}
\hline & DPR & ROA & FCF & F_SIZE & TDTE \\
\hline \hline Mean & 0.156514 & 0.109201 & 0.222852 & 27.68165 & 1.098509 \\
Median & 0.000000 & 0.029114 & 0.032657 & 28.05871 & 0.748997 \\
Maximum & 7.202831 & 45.92847 & 105.7039 & 33.49453 & 23.91730 \\
Minimum & -8.625027 & -0.811080 & -0.809863 & 17.48916 & -10.18817 \\
Std. Dev. & 0.755348 & 1.709704 & 3.947719 & 2.751722 & 2.137737 \\
Observation & & & & & \\
s & 725 & 725 & 725 & 725 & 725 \\
\hline Soun
\end{tabular}

Source: Data analyzed, 2021

Based on the table above, it can be seen that the DPR has an average of 0.156514 with a standard deviation of 0.755348 . The F-Size variable has an average value of 27.68165 with a standard deviation of 2.751722. These two variables have good data distribution and low fluctuation. Meanwhile, ROA has an average value of 0.109201 with a standard deviation of 1.709704 . FCF has an average value of 0.222852 and the TDTE variable has an average value of 1.098509 the average value of the three variables is smaller than the standard deviation value which indicates that the data for these three variables in manufacturing companies during the 2015-2019 period has fluctuations relatively high. 


\section{Correlation Analysis}

Correlation analysis aims to see how big the relationship between the independent variables to the dependent variable. The results of the correlation analysis in this study are as follows:

Table 2. Correlation Analysis

\begin{tabular}{|c|c|c|c|c|c|}
\hline \multicolumn{2}{|c|}{$\begin{array}{c}\text { Correlation } \\
\text { t-Statistic }\end{array}$} & \multirow[b]{2}{*}{ ROA } & \multirow[b]{2}{*}{ FCF } & \multirow[b]{2}{*}{ F_SIZE } & \multirow[b]{2}{*}{ TDTE } \\
\hline Probability & DPR & & & & \\
\hline \multirow[t]{3}{*}{ DPR } & 1.000000 & & & & \\
\hline & ----- & & & & \\
\hline & ----- & & & & \\
\hline \multirow[t]{3}{*}{ ROA } & 0.000486 & 1.000000 & & & \\
\hline & 0.013081 & ----- & & & \\
\hline & 0.9896 & ----- & & & \\
\hline \multirow[t]{3}{*}{ FCF } & 0.009396 & 0.990204 & 1.000000 & & \\
\hline & 0.252655 & 190.6916 & ----- & & \\
\hline & 0.8006 & 0.0000 & ----- & & \\
\hline \multirow[t]{3}{*}{ F_SIZE } & 0.083720 & 0.122994 & -0.127739 & 1.000000 & \\
\hline & 2.259045 & 3.332435 & -3.463093 & ----- & \\
\hline & 0.0242 & 0.0009 & 0.0006 & ----- & \\
\hline \multirow[t]{3}{*}{ TDTE } & 0.049774 & 0.021988 & -0.019243 & 0.048883 & 1.000000 \\
\hline & 1.340020 & 0.591384 & -0.517510 & 1.315979 & ----- \\
\hline & 0.1807 & 0.5544 & 0.6050 & 0.1886 & ----- \\
\hline
\end{tabular}

Source: Data analyzed, 2021

Based on the table above, it can be seen that all the correlation values (relationships) of the variables used in this study. To see the correlation between the independent variables (ROA, FCF, F_SIZE and TDTE) to the dependent variable (DPR) shows that the results of the correlation analysis of the independent variables and the dependent variable in this study are as follows:

1. ROA has a positive correlation with DPR by 0.000486 and is not significant.

2. FCF has a negative correlation with DPR by -0.009396 and is not significant.

3. F_SIZE has a positive correlation with DPR by 0.083720 and is significant

4. TDTE has a negative correlation with DPR by -0.049774 and is not significant.

\section{Normality test}

The normality test carried out in this study was the Jarque Bera test. The results of the Jarque Bera test in this study are as follows: 


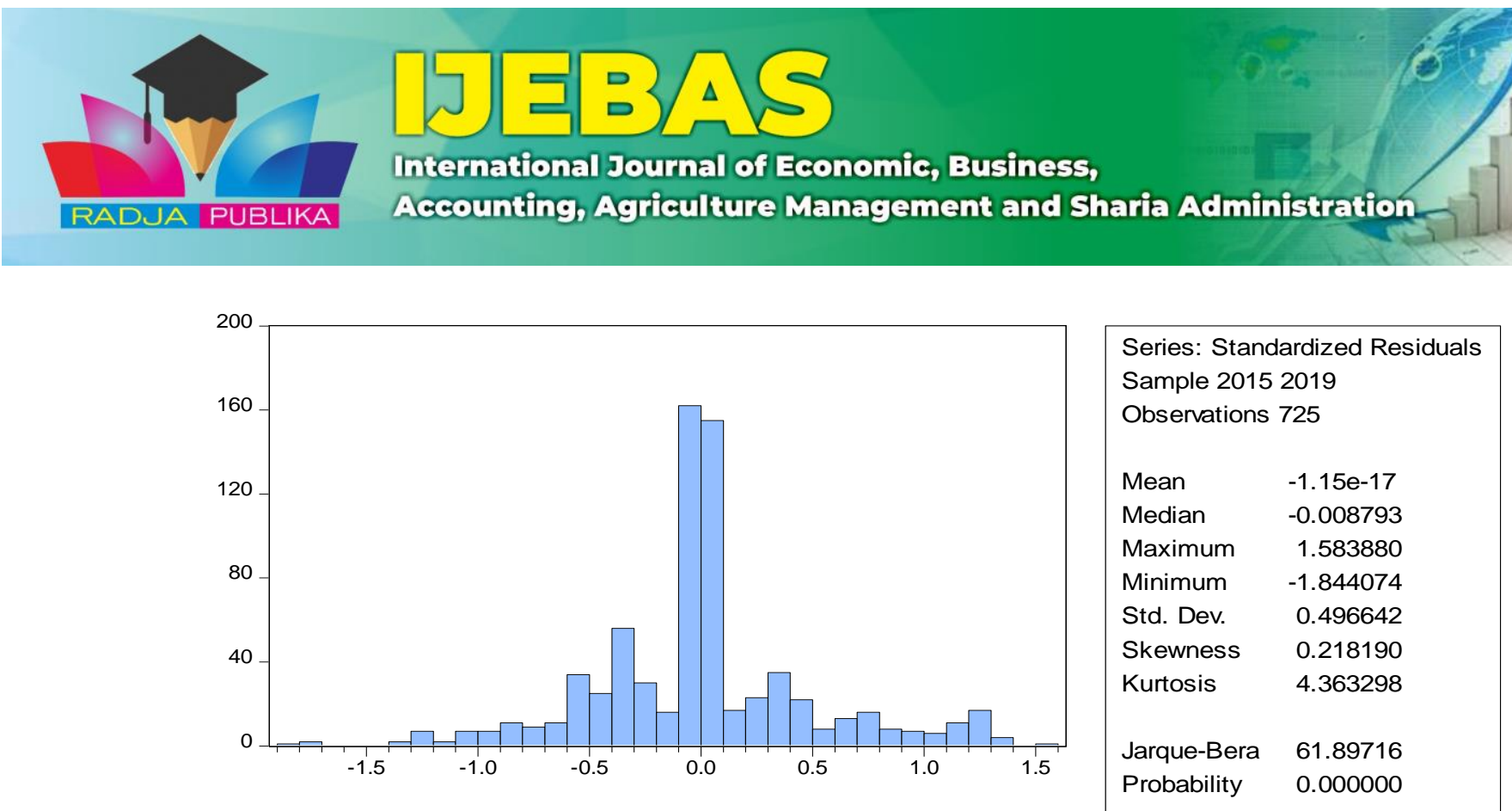

Figure 1. Normality Test

Based on the picture above, it can be seen that the Jarque Bera value is 61.89716 and the probability value is 0.000000 . The Chi Square table value that can be seen at $\mathrm{df}=4-1$ produces a number of 7.81. Therefore, the Jarque Bera value > Chi Square table and the probability value $(0.000000)<0.05$, it can be concluded that the data in this study is not normally distributed. However, because the data in this study is in the form of panel data, where each cross section has a different data trend every year, so the assumption of normality can be ignored (Gujarati \& Porter, 2012).

\section{Model Selection Technique}

The selection of the model aims to determine the best and appropriate model for this research. The selection of the best model was carried out by the Chow test and Housman test.

\section{Chow Test}

The Chow test was conducted to compare the CEM and FEM models. The results of the Chow test in this study are presented in table below.

Table 3. Chow test

\begin{tabular}{llll}
\hline Effects Test & Statistic & d.f & Prob \\
\hline Cross-section F & 1.440039 & $(91,226)$ & 0.0158 \\
Cross-section Chi-square & 147.257929 & 91 & 0.0002 \\
\hline
\end{tabular}

Source: Data analyzed, 2021

Based on the table above, the probability value in the Chi Square row is 0.0002 . This value is below the standard error value of 0.05 . Therefore, based on the Chow Test, the best model is the Fixed Effect Model, so that it is continued on the Housman Test to compare the Fixed Effect Model and the Random Effect Model.

\section{Housman test}

Housman test is used to compare the fixed effect model with the Random effect model (Gujarati \& Porter, 2012). Housman test results in this study are presented in the following table:

Table 4. Housman test

\begin{tabular}{lll}
\hline Test Summary & \multicolumn{1}{c}{ Chi-Sq Statistic } & Prob. \\
\hline Cross-section random & 3.731730 & 0.4435 \\
\hline
\end{tabular}

International Journal of Economic, Business, Accounting, Agriculture Management and Sharia Administration |IJEBAS E-ISSN: 2808-4713 | https://radjapublika.com/index.php/IJEBAS 
Source: Data analyzed, 2021

Based on the table above, the probability value in the Housman test is 0.4435 . This value is above the standard error value in this study (0.05). In other words, the Housman test chose the Random Effect Model (FEM) as the right model, so that the data estimation and hypothesis testing in this study used panel data regression with the Random Effect Model (FEM).

\section{Panel Data Regression Analysis}

Data regression was carried out to see the effect of the independent variable on the dependent variable. Based on the results of the model selection that has been done, the appropriate model for this research is the Random Effect Model. The results of panel data regression with the Random Effect Model can be seen in the table below:

Table 5. Estimation of Panel Data Regression with Random Effect Model

\begin{tabular}{lllll}
\hline Variable & Coefficient & Std. Error & t-Statistic & Prob. \\
\hline \hline C & -0.451690 & 0.253077 & -1.784797 & 0.0747 \\
ROA & 0.164581 & 0.061806 & 2.662858 & 0.0079 \\
FCF & -0.070719 & 0.026176 & -2.701649 & 0.0071 \\
F_SIZE & 0.022507 & 0.009170 & 2.454528 & 0.0143 \\
TDTE & -0.015512 & 0.003374 & -4.596846 & 0.0000 \\
\hline \hline R-squared & 0.022978 & Mean dependent var & 0.156514 \\
Adjusted R-squared & 0.012062 & S.D. dependent var & 0.708464 \\
S.E. of regression & 0.704178 & Sum squared resid & 355.0408 \\
F-statistic & 2.104931 & Durbin-Watson stat & 1.548196 \\
Prob(F-statistic) & 0.033229 & & & \\
\hline
\end{tabular}

Source: Processed Data, 2021 follows:

Based on the table above, the regression equations that can be arranged in this study are as

$$
\mathrm{DPR}=-0.451690+0.164581 \mathrm{ROA}-0.070719 \mathrm{FCF}+0.022507 \mathrm{~F} \_\mathrm{SIZE}-0.015512 \mathrm{TDTE}+\mathrm{er}_{\mathrm{it}}
$$

Based on Equation 1 above, it can be seen that the constant value in this study is -0.451690 . This shows that if ROA, FCF, F_SIZE and TDTE have no value (value 0), then DPR will remain constant with a value of -0.451690

\section{Effect of ROA on Dividend Payout Ratio (DPR)}

Based on the results of panel data regression with the Random Effect Model presented in table 5 above, it was found that the ROA variable has a probability value of 0.0079 . So it can be concluded that ROA has a positive and significant effect on DPR in manufacturing sector companies in Indonesia. The results of this study are in line with research conducted by Jabbouri, 2016 and Kasmir, 2010. ROA is something that investors consider in investing, because the company's ROA reflects that the company remains survive and is evidence that the company is able to compete and can take business opportunities that exist in the market.

\section{The influence of the FCF on the DPR}

Based on the results of panel data regression with the Random Effect Model, it can be seen that FCF has a probability value of 0.0071 . This condition means that FCF has a negative and significant effect on DPR in manufacturing companies on the Indonesia Stock Exchange. These results indicate that the high FCF that exists in the company results in decreased dividend payments. 
This means that there are indications of agency conflicts in manufacturing companies in Indonesia. The results of this study are in accordance with Jabbouri, 2016, (Jensen \& Meckling, 1976).

\section{Effect of F_SIZE on DPR}

Based on the results of panel data regression with the Random Effect Model, it can be seen that F_SIZE has a probability value of 0.0143 . This condition means that F_SIZE has a positive and significant effect on DPR in manufacturing companies on the Indonesia Stock Exchange. These results indicate that the higher the size of the company (F_SIZE) in the company, the dividend payments also increase. The results of this study are in accordance with Holder et al. (1998), Jabbouri, 2016, Jensen et al, 1992. Redding, 2010 and Al-Malkawi, 2011.

\section{Effect of TDTE on DPR}

Based on Table 8 Estimation of Panel Data Regression with Fixed Effect Model, it can be seen that TDTE has a probability value of 0.0000 . These results indicate that there is a negative effect between debts, as measured by Total Debt to Total Equity in manufacturing companies on the Indonesia Stock Exchange. High debt will result in reduced dividend distribution to investors, because some of the available cash is used to pay loan interest as a result of indebtedness to the company. The results of this study are in accordance with Jabbouri, 2016.

\section{CONCLUSION}

Based on the results of data analysis that has been carried out, it was found that ROA and Firm Size had a significant positive effect on the Dividend Payout Ratio. Meanwhile, the FCF and debt variables estimated by TDTE were found to have a negative and significant effect on dividend policy as measured by the DPR in manufacturing companies on the Indonesia Stock Exchange. In this study it can be concluded that all observed variables also affect dividend policy. The most significant variable is Total Debt to Total Equity. Dividend policy can be an indicator in assessing the company's performance by investors. Therefore, investors must be more careful in assessing the company. Because if the company has a high FCF value, while dividend payments are relatively low, it indicates that there is an agency conflict in the company.

\section{REFERENCES}

Al-Kuwari, D., 2007, Determinants of the Dividend Payout Ratio of Companies Listed on Emerging Stock Exchanges: The Case of the Gulf Cooperation Council (GCC) Countries. PhD thesis, University of Wales-Cardiff, UK.

Al-Malkawi, H. N., 2011, Determinant of Corporate Dividend Policy in Jordan, Journal of Economic and Administrative Since 23, 44-71

Brigham, F. and J. Gordon, 1968, Leverage, Dividend Policy, and the Cost of Capital, Journal of Finance 23, 85-103.

Brigham, Eugene F. dan Houston, Joel F. (2013), Dasar-dasar Manajemen Keuangan, Edisi 11 : Salemba Empat, Jakarta.

Fama, E. and K. French, 2001, Disappearing Dividends: Changing Firm Characteristics or Lower Propensity to Pay?, Journal of Financial Economics 60, 3-43.

Faccio, M. and L. Lang, 2002, The Ultimate Ownership of Western European Corporations, Journal of Financial Economics 65, 365-395.

Gill, A., Biger, N., dan Tibrewala, R. (2010). Determinants of Dividend Payout Ratios: Evidence from United States. The Open Business Journal. Vol. 3, hal. 8-14

Ghozali, Imam. (2012). Aplikasi Analisis Multivariate Dengan Program SPSS. Semarang: Badan Penerbit Universitas Diponegoro. 
Gujarati, D. N. (2012). Dasar-dasar Ekonometrika (5th ed.). Jakarta: Salemba Empat.

Holder, M., F. Langrehr, and J. Hexter, 1998, Dividend Policy Determinants: An Investigation of the Influences of Stakeholder Theory, Financial Management 27, 73-82.

Ilham, R. (2019). N et al.(2019). Comparative of the Supply Chain and Block Chains to Increase the Country Revenues via Virtual Tax Transactions and Replacing Future of Money. International Journal of Suplly Chain Management, 8(5).

Jabbouri, I. (2016). Determinants of Corporate Dividend Policy in Emerging Markets: Evidence from MENA Stock Markets. Research in International Business and Finance, 37, 283-298. https://doi.org/10.1016/j.ribaf.2016.01.018

Jensen, M., 1986, Agency Costs of Free Cash Flow, Corporate Finance, and Takeovers, American Economic Review 76, 323-329.

Jensen, M. and W. Meckling, 1976. Theory of the Firm: Managerial Behavior, Agency Costs and Ownership Structure, Journal of Financial Economics 3, 305-360.

Kasmir. (2010). Pengantar Manajemen Keuangan. Jakarta: Kencana. Prenada Media Group.

La Porta, R., F. Lopez-De-Silanes, A. Shleifer and R. Vishny, 2000, Agency Problems and Dividend Policy around the World, Journal of Finance 55, 1-33.

Litzenberger, R., and K. Ramaswamy, 1982, The Effects of Dividends on Common Stock Prices: Tax Effects or Information Effects?, Journal of Finance 37, 429- 443.

Mollah, S., K. Keasey, and H. Short, 2002, The Influence of Agency Costs on Dividend Policy in an Emerging Market: Evidence from the Dhaka Stock Exchange, Working Paper www.bath.ac.uk.

Munawir. (2012). Analisis Laporan Keuangan. Liberty. Yogyakarta

Redding, L., 2010, Firm Size and Dividend Payouts., Journal of Financial Intermediation 6, 224-248

Sartono, R.Agus, (2011), Manajemen Keuangan (Teori dan Aplikasi), Edisi Keempat, BPFE : Yogyakarta.

Sawicki, J., 2005, An Investigation into the Dividend of Firms in East Asia , Working Paper, Nanyang Technological University, Singapore.

Setyawan dan Sulistyowati (2018) Analisis Pertumbuhan Penjualan Dan Perputaran Modal Kerja Terhadap Profitabilitas PT. Tiga Pilar Sejahtera Food, Tbk Tahun 2012-2016

Tandelilin, E. (2010). Analisis Investasi dan Manajemen Portofolio (1st ed.). Yogyakarta: BPFE. 